\title{
APLIKASI SMART CARD GAME UNO ACOUNTING SEBAGAI ALAT EVALUASI PEMBELAJARAN AKUNTANSI
}

\author{
Oleh: \\ Rini Agustin Eka Yanti \& Yuyun Susanti \\ Dosen Program Studi Pendidikan Akuntansi FKIP Universitas Galuh Ciamis \\ Jl. R.E. Martadinata No. 150, Ciamis 46274 Jawa Barat \\ Email: riniagustin.eka@gmail.com
}

\begin{abstract}
ABSTRAK
Proses pembelajaran haruslah menjadi sebuah proses yang dapat mengembangkan seluruh potensi seseorang. Seluruh potensi tersebut hanya mungkin dapat berkembang manakala seseorang terbebas dari rasa takut dan menegangkan. Salah satu alat evaluasi yang dapat mengurangi tingkat kecemasan peserta didik adalah dengan permainan smart card game uno accounting. Tujuan penelitian ini untuk mengetahui Peningkatan hasil belajar siswa dengan aplikasi smart card game uno accounting sebagai alat evaluasi pembelajaran akuntansi pada pokok bahasan persamaan dasar akuntansi. Serta menilai kelayakan smart card game uno accounting untuk digunakan sebagai alat evaluasi pembelajaran akuntansi pada pokok bahasan persamaan dasar akuntansi. Metode penelitian yang digunakan yaitu metode penelitian pengembangan (Reaserch and Development). Hasil penelitian menunjukan terdapat peningkatan hasil belajar siswa dengan aplikasi smart card uno accounting sebagai alat evaluasi pembelajaran akuntansi pada pokok bahasan persamaan dasar akuntansi di SMK Negeri 1 Ciamis serta di SMK Bahrul Ulum Kawali Ciamissmart card game uno accounting sangat layak digunakan sebagai alat evaluasi pembelajaran akuntansi pada pokok bahasan persamaan dasar akuntansi.
\end{abstract}

Kata Kunci: Smart card game uno accounting, alat evaluasi

\section{PENDAHULUAN}

Dalam dunia pendidikan, belajar dapat dimaknai sebagai suatu proses yang menunjukan adanya perubahan yang sifatnya positif sehingga akan menghasilkan keterampilan, kecakapan dan pengetahuan baru sebagai akumulasi pengalaman dalam proses pembelajaran. Untuk meraih prestasi yang tinggi dalam belajar, seseorang harus memiliki IQ (intelligence quotient) yang tinggi, karena intelegensi merupakan bekal potensial yang akan memudahkan proses pembelajaran, sehingga pada akhirnya akan menghasilkan prestasi belajar yang optimal. Namun dewasa ini berkembang bahwa seseorang dikatakan cerdas bukan karena kemampunanya dalam memahami sesuatu, tetapi bagaimana seseorang mampu mengembangkan dirinya secara afektif dan psikomotorik. Untuk mencapai hal tersebut, maka proses belajar sebaiknya dikemas dalam upaya meraih prestasi belajar secara afektif, kognitif dan psikomotorik yang memuaskan. Hasil dari proses belajar akan tercermin dalam prestasi belajarnya.

Proses pembelajaran yang baik harus diawali dengan perencanaan yang bijak, serta didukung dengan komunikasi yang baik, juga harus didukung dengan pengembangan strategi yang mampu membelajarkan siswa. Proses pembelajaran haruslah menjadi sebuah proses yang dapat mengembangkan seluruh potensi seseorang. Seluruh potensi tersebut hanya mungkin dapat berkembang manakala seseorang terbebas dari rasa takut dan menegangkan. Artinya proses proses pembelajaran harus diupayakan menjadi sebuah kegiatan yang menyenangkan (enjoyful learning).

Akuntansi merupakan mata pelajaran yang menuntut siswa untuk memiliki kemampuan yang mengkombinasikan antara hapalan dan hitungan. Akuntansi merupakan bagian dari rumpun ilmu sosial yang secara umum biasanya berbentuk teori-teori serta dalam pembelajaran akuntansi menuntut siswa mengembangkan logikanya untuk menghitung dan menganalisis setiap transaksi yang terjadi.

Evaluasi pembelajaran akuntansi sering kali menggunakan media latihan dan tugas berupa lembaran soal yang dikerjakan secara individu oleh siswa dan diawasi guru. Tujuan kegiatan evaluasi yaitu untuk mengetahui kemampuan siswa dalam memahami materi akuntansi yang telah diajarkan. Hal tersebut cenderung membuat siswa jenuh dengan rutinitas pembelajaran yang dilaksanakan. Evaluasi yang dilaksanakan biasanya bersifat 
resmi dan cenderung kaku, sehingga membuat siswa secara psikologis memiliki ketakutan dan rasa tegang yang bisa menyebabkan siswa kurang optimal dalam menyelesaikan soal-soal yang diberikan.

Persamaan dasar akuntansi merupakan hal yang wajib dipahamai oleh siswa yang akan belajar akuntansi. Hal ini disebabkan karena persamaan dasar akuntansi merupakan rumus dasar yang berlaku dalam praktek akuntansi. Misalnya pada saat membuat jurnal, memposting ke buku besar sampai pada saat pelaporan keuangan. Fungsi dasar persamaan akuntansi adalah untuk mengetahui tingkat keseimbangan antara harta dan sumber-sumber pemerolehan harta tersebut. Maka dengan memahami persamaan akuntansi otomatis siswa akan mudah untuk memahami materi-materi ekonomi pada level berikutnya.

Untuk memudahkan dalam pemahaman persamaan akuntansi salah satunya dengan menciptakan suasana belajar yang menyenangkan. Salah satu upaya untuk menciptakan suasana menyenangkan adalah dengan mencoba alat evaluasi menggunakan kartu pintar akuntansi berbentuk kartu uno. Kartu uno merupakan salah satu permainan yang banyak digemari para pelajar. Dengan permainan kartu dapat dijadikan media untuk melatih cara kerja otak dengan menyusun strategi untuk memenangkan permainan dan menarik minat siswa untuk belajar akuntansi dengan cara yang menyenangkan.

Masalah dalam penelitian ini dirumuskan sebagai berikut 1) Apakah terdapat peningkatan hasil belajar siswa dengan aplikasi smart card uno accounting sebagai alat evaluasi pembelajaran akuntansi pada pokok bahasan persamaan dasar akuntansi, 2) Apakah smart card game uno accounting layak digunakan sebagai alat evaluasi pembelajaran akuntansi pada pokok bahasan persamaan dasar akuntansi.

\section{METODE PENELITIAN}

Metode penelitian yang digunakan yaitu metode penelitian pengembangan (Reaserch and Development) yaitu metode penelitian yang menghasilkan produk baru untuk menguji keefektifan suatu produk (Sugiyono, 2012). Dalam hal ini metode pengembangan yang digunakan merupakan adaptasi dari teori Model pengembangan Four-D (4-D) Thiagarajan, dkk (1974). Pada penelitian ini akan dilaksanakan model pengembangan ini dalam 4 tahap yaitu define, desain, developdan disseminate.
Tahap pertama yaitu tahap pendefinisian dengan tujuan untuk menetapkan dan mendefinisikan syarat-syarat pembelajaran. Tahap ini dilakukan dengan melakukan analisis tujuan dalam batasan materi pelajaran yang akan dikembangkan perangkatnya. Ada lima langkah pokok didalam tahap ini, yaitu analisis ujung depan, analisis siswa, analisis tugas, analisis konsep, dan perumusan tujuan pembelajaran.

Tahap kedua yaitu tahap pendefinisian dengan melakukan perancangan perangkat pembelajaran yakni peneliti melakukan penyusunan tes. Langkah ini merupakan jembatan yang menghubungkan tahap pendefinisian dengan perancangan. Disamping itu didalam tahap ini juga dilakukan pemilihan media yang sesuai tujuan, untuk menyampaikan materi pelajaran. Termasuk pula dalam tahap ini adalah pemilihan format.

Tahap ketiga yaitu tahap pengembangan yang bertujuan untuk menghasilkan perangkat pembelajaran yang sudah direvisi berdasarkan masukan para pakar. Validasi perangkat oleh pakar diikuti dengan revisi kemudian simulasi, yaitu kegiatan mengoperasionalkan rencana pelajaran. Kegiatan ini ditujukan untuk mengecek keterlaksanaan perangkat, kecocokan waktu, kerja alat dan sebagainya. Terakhir uji coba terbatas dengan siswa yang sesungguhnya.

Tahap keempat yaitu tahap penyebaran yang merupakan tahapan penggunaan perangkat yang telah dikembangkan pada skala yang lebih luas misalnya di kelas lain, di sekolah lain, oleh guru yang lain dan sebagainya. Tujuan tahap ini juga untuk menguji efektivitas penggunaan perangkat didalam proses belajar mengajar.

Teknik pengumpulan data adalah cara yang digunakan untuk mengumpulkan data penelitian. Adapun teknik yang digunakan dalam penelitianini adalah :

1. Metode observasi nonpartisipasif, yaitu peneliti tidak terlibat langsung dalam proses pembelajaran yang dilaksanakan.

2. Metode tes, dengan menggunakan tes awal (pre test) dan test akhir (post test) untuk mengetahui prestasi siswa dalam penguasaan materi persamaan dasar akuntansi

3. Metode wawancara, untuk mengetahui halhal yang lebih mendalam dari responden.

4. Metode angket, untuk mengetahui tengtang kelayakan smart card uno accounting ini sebagai alat evaluasi pembelajaran.

Teknik analisis data merupakan cara yang dilakukan untuk menganalisis data-data yang telah dikumpulkan dengan melakukan 
perhitungan untuk menjawab rumusan masalah, dan melakukan perhitungan untuk menguji hipotesis yang telah dirumuskan sebelumnya. Teknik analisis data dilakukan dengan menggunakan langkah-langkah sebagai berikut:

1. Untuk mengetahui Peningkatan hasil belajar siswa dengan aplikasi smart card uno accounting sebagai alat evaluasi pembelajaran akuntansi pada pokok bahasan persamaan dasar akuntansi.dilakukan dengan menguji $N$-Gain

Perbandingan nilai gain yang dinormalisasi ( $N$-Gain) antara kelompok dapat dihitung dengan menggunakan rumus:

$$
\boldsymbol{N}-\boldsymbol{G a i n}=\frac{\text { Skor posttes }- \text { skor pretest }}{\text { skor maksimum }- \text { skor pretest }}
$$

Sumber: Hake (2008:1)

$\begin{array}{lcc}\text { Kemudian } & N \text {-Gain } & \text { tersebut } \\ \text { diinterpretasikan } & \text { dengan kriteria } & \text { sebagai } \\ \text { berikut: } & & \end{array}$

\section{Tabel 4.1}

\section{Kriteria $N$-Gain}

\begin{tabular}{c|c} 
N-Gain & Kriteria \\
\hline $\mathrm{g}>0,70$ & Tinggi \\
\hline $0.30<\mathrm{g} \leq 0,70$ & Sedang \\
\hline $\mathrm{g} \leq 0,30$ & Rendah
\end{tabular}

Sumber: Hake (2008:1)

2. Untuk mengetahui Kelayakan smart card game uno accounting digunakan sebagai alat evaluasi pembelajaran akuntansi pada pokok bahasan persamaan dasar akuntansi dilakukan dengan menganalisis angket pendapat siswa secara kualitatif berdasarkan skala Guttman.

\section{HASIL PENELITIAN DAN PEMBAHASAN}

Peningkatan hasil belajar peserta didik aplikasi smart card uno accounting sebagai alat evaluasi pembelajaran akuntansi pada pokok bahasan persamaan dasar akuntansi, diperoleh dari hasil pengukuran awal (pretest) dan pengukuran akhir (posttest) dapat diketahui dengan menggunakan rumus $N$-Gain. $N$-Gain digunakan untuk mengetahui peningkatan hasil belajar peserta didik melalui pretest ke posttest. Penelitian ini menggunakan nilai dari hasiltes awal (pretest) dan hasil tes akhir (posttest)
Tabel 5.5

Kategori N-Gain SMK Negeri 1 Ciamis

\begin{tabular}{c|c} 
Kategori & Frekuensi N-Gain \\
\hline Tinggi & 27 \\
\hline Sedang & 11 \\
\hline Rendah & 1 \\
\hline Kategori Rata-rata & 0,79 \\
\hline Jumlah Peserta Didik & 39
\end{tabular}

Sumber: Data Diolah Tahun 2017

Berdasarkan perhitungan N-Gain peningkatan hasil belajar peserta didik setelah melakukan pretest ke posttest bernilai 0,79 dengan kategori tinggi. Sehingga dapat disimpulkan bahwa terdapat peningkatan hasil belajar siswa dengan aplikasi smart card uno accounting sebagai alat evaluasi pembelajaran akuntansi pada pokok bahasan persamaan dasar akuntansi di SMK Negeri 1 Ciamis.

Tabel 5.10

Kategori N-Gain SMK Bahrul Ulum Kawali

\begin{tabular}{c|c} 
Kategori & Frekuensi N-Gain \\
\hline Tinggi & 0 \\
\hline Sedang & 5 \\
\hline Rendah & 14 \\
\hline Kategori Rata-rata & 0,27 \\
\hline Jumlah Peserta Didik & 19
\end{tabular}

Sumber: Data Diolah Tahun 2017

Berdasarkan perhitungan $N$-Gain peningkatan hasil belajar peserta didik setelah melakukan pretest ke posttest bernilai 0,27 dengan kategori rendah. Sehingga dapat disimpulkan bahwa terdapat peningkatan hasil belajar siswa dengan aplikasi smart card uno accounting sebagai alat evaluasi pembelajaran akuntansi pada pokok bahasan persamaan dasar akuntansi di SMK Bahrul Ulum. 
Tabel 5.11

Rekapitulasi Respon Siswa Berdasarkan Ketertarikan

\begin{tabular}{|c|c|c|}
\hline \multirow{2}{*}{ Peryataan } & \multicolumn{2}{|c|}{$\%$} \\
\hline & $\mathrm{Y}$ & $\mathrm{T}$ \\
\hline 1. Tampilannya Menarik & 100 & 0 \\
\hline $\begin{array}{l}\text { 2. Kartu ini Membuat saya } \\
\text { lebih bersemangat belajar } \\
\text { akuntansi }\end{array}$ & 96 & 4 \\
\hline $\begin{array}{l}\text { 3. Dengan menggunakan kartu } \\
\text { akuntansi ini dapat membuat } \\
\text { belajar akuntansi tidak } \\
\text { membosankan }\end{array}$ & 98 & 2 \\
\hline $\begin{array}{l}\text { 4. Kartu Akuntansi ini } \\
\text { mendukung saya menguasai } \\
\text { pelajaran akuntansi } \\
\text { khususnya persamaan dasar } \\
\text { akuntansi }\end{array}$ & 87 & 13 \\
\hline $\begin{array}{l}\text { 5. Bermain kartu akuntansi ini } \\
\text { dapat meningkatkan } \\
\text { motivasi terhadap sikap dan } \\
\text { belajar saya }\end{array}$ & 98 & 2 \\
\hline 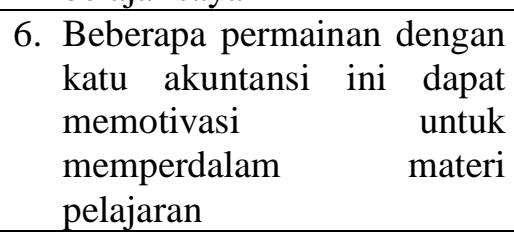 & 92 & 8 \\
\hline Total & 95 & 5 \\
\hline
\end{tabular}

Tabel 5.12

Rekapitulasi Respon Siswa Berdasarkan Materi

\begin{tabular}{|c|c|c|}
\hline \multirow{2}{*}{ Peryataan } & \multicolumn{2}{|c|}{$\%$} \\
\hline & $Y$ & $\mathrm{~T}$ \\
\hline $\begin{array}{l}\text { 1. Penyampaian materi dengan } \\
\text { kartu dikaitkan bisa dikaitkan } \\
\text { dengan kehidupan sehari-hari }\end{array}$ & 81 & 19 \\
\hline 2. Materinya mudah dipahami & 94 & 6 \\
\hline $\begin{array}{l}\text { 3. Dengan menggunakan kartu } \\
\text { bisa mendorong saya untuk } \\
\text { menemukan konsep sendiri }\end{array}$ & 75 & 25 \\
\hline 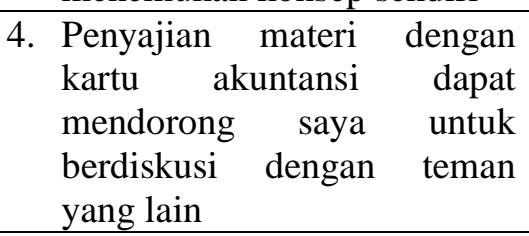 & 96 & 4 \\
\hline $\begin{array}{l}\text { 5. Setiap siswa bisa mengukur } \\
\text { pemahamannya setelah } \\
\text { bermain kartu akuntansi }\end{array}$ & 98 & 2 \\
\hline $\begin{array}{llr}\text { 6. Dengan } & \text { bermain } & \text { kartu } \\
\text { akuntansi } & \text { dapat } & \text { menguji }\end{array}$ & 96 & 4 \\
\hline
\end{tabular}

\begin{tabular}{l|l|l|l}
$\begin{array}{l}\text { seberapa jauh pemahaman } \\
\text { saya terhadap persamaan } \\
\text { dasar akuntansi }\end{array}$ & & \\
\hline Total & 90 & 10
\end{tabular}

Tabel 5.12

Rekapitulasi Respon Siswa

Berdasarkan Bahasa

\begin{tabular}{l|l|l}
\multicolumn{2}{c|}{ Peryataan } & \multicolumn{2}{|c}{$\%$} \\
\cline { 2 - 3 } & $\mathrm{Y}$ & $\mathrm{T}$ \\
\hline $\begin{array}{l}\text { 1. Kalimat penjelasan dalam } \\
\text { kartu akuntansi mudah } \\
\text { dipahami }\end{array}$ & 71 & 29 \\
\hline $\begin{array}{l}\text { 2. } \\
\text { Bahasa yang digunakan } \\
\text { dalam kartu ini sederhana dan } \\
\text { mudah dimengerti }\end{array}$ & 79 & 21 \\
\hline $\begin{array}{l}\text { Huruf yang digunakan } \\
\text { sederhana dan mudah dibaca. }\end{array}$ & 96 & 4 \\
\hline Total & 82 & 18
\end{tabular}

Berdasarkan hasil perhitungan terlihat bahwa berdasarkan ketertarikan siswa terhadap kartu akuntansi yang dinilai dari tampilan yang menarik, meningkatkan semangat belajar, mendukung dalam meningkatkan pemahaman siswa, serta dapat meningkatkan motivasi belajar siswa total $95 \%$ siswa tertarik dengan permainan kartu akuntansi. Selanjutnya berdasarkan materi yang disampaikan yaitu Penyampaian materi dengan kartu bisa dikaitkan dengan kehidupan sehari-hari, Materinya mudah dipahami, bisa mendorong siswa untuk menemukan konsep sendiri, dapat menguji seberapa jauh pemahaman terhadap persamaan dasar akuntansi, total $90 \%$ siswa bisa memahami materi yang disampaikan dengan bantuan kartu akuntansi ini. Sedangkan dari sisi bahasa, penggunaan kalimat yang mudah dipahami, bahasa dan huruf yang sederhana, total $82 \%$ siswa dapat memahaminya. Sehingga kelayakan alat evaluasi dengan menggunakan aplikasi kartu uno akuntansi ini berdasarkan respon siswa ditinjau dari sisi ketertarikan, materi dan bahasa adalah sangat layak digunakan.

Hasil penelitian menunjukan terdapat peningkatan hasil belajar siswa dengan aplikasi smart card uno accounting sebagai alat evaluasi pembelajaran akuntansi pada pokok bahasan persamaan dasar akuntansi. Namun terdapat perbedaan antara pendingkatan hasil di SMK Negeri 1 Ciamis yang termasuk pada kategori tinggi dengan peningkatan hasil belajar di SMK Bahrul Umum yang berada pada kategori rendah. 
Perbedaan tersebut dapat disebabkan oleh beberapa faktor baik faktor internal maupun faktor ekternal, salah satu faktor yang paling mungkin bisa menyebabkan perbedaan tersebut adalah karena secara letak geografis SMK Negeri 1 Ciamis berada di pusat kota dengan berbagai fasilitas kelengkapan sekolah yang memadai sedangka SMK Bahrul Ulum secara letak geografis berada cukup jauh dari pusat kota yaitu sekitar $18 \mathrm{Km}$ ke arah utara Kabupaten Ciamis. Kemudian dari segi fasilitas juga tidak selengkap di SMK negeri serta banyak kegiatan yang berbenturan dengan kegiatan pesantren.

Hal tersebut diatas sejalan dengan pendapat Djamarah dan Zain (2010:109) bahwa hasil belajar dipengaruhi oleh beberapa faktor diantaranya adalah sebagai berikut: "1) Tujuan;

2) Guru; 3) Anakdidik; 4) Kegiatan pengajaran; 5) Bahan dan alat evaluasi; 6) Suasana evaluasi". Lebih lanjut faktor tersebut dapat dijelaskan sebagai berikut:

1) Tujuan

Berhasil atau tidaknya tergantung dari kejelasan perumusan tujuan pengajaran, karena tujuan merupakan pangkal dari kegiatan pengajaran.

2) Guru

Kepribadian guru, cara pandang guru terhadap peserta didik, dan latar belakang pendidikan serta pengalaman guru akanmenentukan kegiatan pengajaran yang pada akhirnya kakan menentukan hasil belajar.

3) Peserta didik

Peserta didik dengan segala perbedaan latar belakang, kepribadian,minta, bakat dan kecerdasan yang menyatu dalam sistem pengajaran dalam kelas menentukan belajar.

4) Kegiatan pengajaran

Kegiatan pengajaran yang dilakukan oleh guru seperti gaya mengajar dan metode yang dipakai menentukan dalam pencapaian hasil belajar siswa

5) Bahan dan Alat evaluasi

Evaluasi memiliki cakupan bukan hanya pada bahan ajar tetapi pada keseluruhan proses belajar mengajar. Bahan dan alat evaluasi yang dipakai menentukan hasil belajar siswa.

6) Suasana evaluasi

Suasana evaluasi seperti pengetatan pengajar, suasana hati peserta didik, dan kenyamanan tempat evaluasi berpengaruh juga terhadap hasil belajar

\section{PENUTUP \\ Simpulan}

Terdapat peningkatan hasil belajar siswa dengan aplikasi smart card uno accounting sebagai alat evaluasi pembelajaran akuntansi pada pokok bahasan persamaan dasar akuntansi di SMK Negeri 1 Ciamis serta di SMK Bahrul Ulum Kawali Ciamis. Smart card game uno accounting sangat layak digunakan sebagai alat evaluasi pembelajaran akuntansi pada pokok bahasan persamaan dasar akuntansi.

\section{Saran}

Alat evaluasi yang digunakan hanya berupa soal mengenai persamaan dasar akuntansi sehingga masih bisa digunakan soal pada materi lain seperti penjurnalan dan penyusunan laporan keuangan. Untuk peneliti lain penggunaan alat evaluasi ini sanagat mungkin untuk dikembangkan menjadi berbagai permainan sesuai dengan kreatifitas guru, serta dapat diterapkan pada materi lainnya.

\section{DAFTAR PUSTAKA}

Djamarah, Syaiful Bahri dan aswan zain. 2010. Strategi Belajar Mengajar. Jakarta: Rineka Cipta.

Hake. R. R. Analyzing Change/Gain Scores. Dept. of Physics, Indiana University 24245 Hatteras Street, Woodland Hills, CA, 91367 USA.

http://www.physics.indiana.edu/ sdi/Ana lyzingChange-Gain diakses Mei 2016

Sugiyono. 2012. Metode Penelitian Pendidikan (Pendekatan Kuantitatif, Kualitatif dan $R$ $\& D)$. Bandung: Alfabeta.

Thiagarajan, S., Semmel, D. S \& Semmel, M. I. 1974. Instructional Development for Training Teachers of Expectional Children. Minneapolis, Minnesota: Leadership Training Institute/Special Education, University of Minnesota. 
